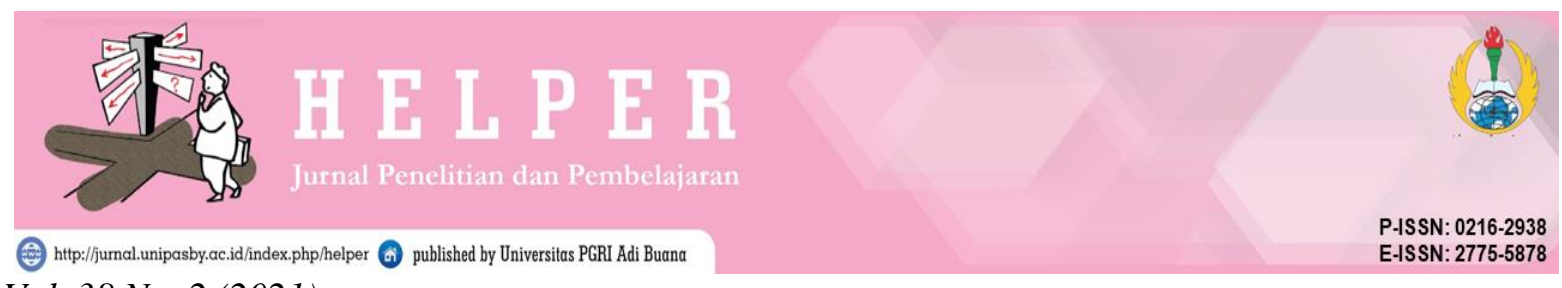

Vol. 38 No. 2 (2021)

\title{
PERAN GURU BIMBINGAN DAN KONSELING DALAM MENCEGAH PERILAKU BULLYING SISWA KELAS X IPS 2 DI SMA HANG TUAH 4 SURABAYA TAHUN AJARAN 2020/2021
}

\author{
Rohani Gultom \\ ${ }^{1}$ Bimbingan dan Konseling, Universitas PGRI Adi Buana Surabaya, Surabaya, Indonesia \\ *Email: rohanigultom28@gmail.com \\ Tamsil Muis \\ ${ }^{2}$ Bimbingan dan Konseling, Universitas PGRI Adi Buana Surabaya, Surabaya, Indonesia \\ *Email: tamsil.muis@unipasby.ac.id
}

\begin{abstract}
Abstrak
Penelitian ini bertujuan untuk mendeskripsikan peran guru bimbingan dan konseling dalam mencegah perilaku bullying siswa. Penelitian ini menggunakan penelitian deskriptif kuantitatif. Populasi dalam penelitian ini terdiri dari 139 subjek. Sedangkan sampel dalam penelitian ini terdiri dari 30 subjek. Metode pengumpulan data menggunakan angket berupa kuisioner dan wawancara. Analisis data dalam penelitian ini menggunakan uji F. Hasil penelitian yang diperolah adalah peran guru bimbingan dan konseling terbukti telah mampu mencegah perilaku bullying siswa kelas X IPS 2 di SMA Hang Tuah 4 Surabaya, dengan perolehan uji F $0,002<0,05$. Adapun peran guru bimbingan dan konseling dalam mencegah perilaku bullying siswa memberikan program bimbingan dan konseling yang dilaksanakan di sekolah dengan memberikan bimbingan klasikal, konseling individual, konseling kelompok, dan layanan informasi.
\end{abstract}

Kata Kunci: Peran Guru Bimbingan dan Konseling, Perilaku Bullying

\begin{abstract}
Abstact
This study aims to describe the role of guidance and counseling teachers in preventing student bullying behavior. This research uses descriptive quantitative research. The population in this study consisted of 139 subjects. While the sample in this study consisted of 30 subjects. Methods of data collection using a questionnaire in the form of questionnaires and interviews. Analysis of the data in this study using the $\mathrm{F}$ test. The results obtained are the role of guidance and counseling teachers proven to have been able to prevent bullying behavior in class X IPS 2 students at SMA Hang Tuah 4 Surabaya, with an F test of $0.002<0.05$. The role of guidance and counseling teachers in preventing student bullying behavior is to provide guidance and counseling programs that are implemented in schools by providing classical guidance, individual counseling, group counseling, and information services
\end{abstract}

Keywords: The Role of Guidance and Counseling Teachers, Bullying Behavior 


\section{PENDAHULUAN}

Masa remaja merupakan tahap perkembangan mencari jati dirinya yang sesungguhnya. Biasanya pada tahap perkembangan memiliki tingkat rasa ingin tahu yang besar dalam mencoba sesuatu hal yang baru diketahui dari lingkungan sekitarnya, seperti: dalam lingkup keluarga yang paling utama, lingkungan sekolah dan lingkungan masyarakat. Pengetahuan yang baru remaja tersebut ketahui dapat diterima dan ditangkap sesuai dengan kepribadiannya masing-masing. Setiap remaja memiliki kemampuan yang berbeda-beda untuk mencapai kematangan kepribadian agar dapat menghadapi tantangan-tantangan yang dialami oleh remaja tersebut secara kuat, baik ketika berada dilingkungan sekolah maupun dalam lingkungan masyarakat.

Menurut (Priyatna, 2010) bullying merupakan tindakan disengaja oleh pelaku terhadap korbannya. Perilaku bullying biasa terjadi karena ketidaksukaan antar siswa yang dilakukan untuk mempermalukan siswa di kalangan umum, baik di depan teman, ataupun mempermalukan korban di dunia sosial media, kegiatan tersebut dapat berupa mengolok teman, bersikap iri terhadap teman, merendahkan teman, mengucilkan teman, dan mengejek yang niatnya hanya bercanda dan dianggap serius oleh korban bullying tersebut, sehingga timbul rasa tidak nyaman pada diri korban yang menyebabkan perkelahian antar teman karena korban tidak terima dibully oleh temannya sendiri secara terus menerus.

Dalam lingkungan sekolah terdapat beberapa macam perilaku siswa, seperti dalam bentuk perilaku positif atau perilaku negatif. salah satu contoh perilaku negatif adalah bullying seringkali terjadi di sekolah. bullying dapat menyinggung atau menyakiti perasaan seseorang. Adanya bullying, dapat membuat siswa menjadi merasa diasingkan ketika berada di lingkungan sekolah. ketakutan yang dialami oleh siswa yang menjadi korban bullying di lingkungan sekolah dapat mengganggu proses pembelajaran kemudian dapat menghambat perkembangan yang menjadi korban. Pelaku bullying lebih cenderung terjadi pada golongan hebat terhadap seseorang yang dianggap rendah untuk menjatuhkan korban bullying tersebut. Bullying adalah tindakan yang menyakiti individu yang satu ke individu lainnya secara verbal, fisik atau psikologis dan juga melalui media sosial (cyberbullying). Sehingga, korban merasa tertekan, trauma, dan pasrah. Seorang yang melakukan bullying tidak mengenal jenis kelamin dan umur. bullying sering terjadi disetiap sekolah, yang dilakukan siswa baik antar teman kelas ataupun antar kakak kelas terhadap adik kelasnya. 
Dengan adanya internet yang canggih dapat memudahkan setiap orang untuk mencari informasi dan berkomunikasi. Dampak positif internet sangat bermanfaat bagi banyak orang seperti, memudahkan banyak orang khususnya siswa dalam mengakses informasi, pengetahuan, bersosialisasi, dan berkomunikasi. Kemudian dampak negatif dari penggunaan internet jika disalahgunakan oleh siapapun. Sebagai contoh: terdapat sebagian anak yang menjadi korban pelecehan dikenal dengan istilah cyberbullying yaitu, tingkah laku sosial yang melecehkan atau merendahkan seseorang yang banyak menimpa anak-anak dan remaja yang dilakukan secara online. Contoh pelecehan yang dilakukan melalui media sosial adalah dalam bullying.

Penelitian ini didasarkan Perilaku bullying yang seringkali terjadi di SMA Hang Tuah 4 Surabaya, seperti saat kegiatan belajar mengajar di dalam kelas atau ketika jam istirahat sedang berlangsung siswa saling mengejek, mempermalukan teman, dan memukul. Hal tersebut jadi didasari hanya karena bercanda kemudian dianggap serius oleh salah satu temannya sehingga terjadilah aksi bullying tersebut. kemudian salah satu korban bullying tersebut, tidak membalas aksi dari pelaku bullying tersebut karena korban takut dipukul oleh pelaku tersebut.

Perilaku bullying di kalangan remaja khususnya pada siswa-siswi di SMA Hang Tuah 4 Surabaya sangat penting untuk diteliti. Karena, yang pertama bullying dapat mempengaruhi kegiatan belajar mengajar disekolah, kedua perilaku bullying merupakan peristiwa yang turun temurun khususnya yang terjadi di setiap sekolah, ketiga perilaku bullying di sekolah di SMA Hang Tuah 4 Surabaya dapat selesaikan oleh guru bimbingan dan konseling (selaku konselor sekolah), kedua peran guru bimbingan dan konseling sangat penting untuk mencegah perilaku bullying yang terjadi di lingkungan sekolah

Dampak negatif bullying yang dialami oleh korban yaitu, korban kurang percaya diri, depresi, pemalu, mengalai prestasi yang menurun, dan korban juga lebih mudah cemas dan stress. Dampak bullying yang buruk bagi korbannya, adapun dampak tersebut berupa mengurung diri karena merasa ketakutan, meminta untuk pindah sekolah agar tidak bertemu lagi dengan orang yang membullynya, prestasi belajarnya akan menurun, kesulitan untuk bersosialisasi serta akan mengalami rendah diri (Sejiwa, 2008). Dampak negatif bullying yang dialami oleh korban yaitu: Rendah diri serta akan membuat seseorang menjadi sakit mentalnya, ini meningkatkan seseorang untuk melukai dirinya sendiri bahkan ada yang mencoba bunuh diri, terbentuknya sebuah geng yang dianggap paham dengan mereka atau sebaliknya ini juga 
dapat membuat seseorang menjadi benci terhadap sekelompok orang atau komunitas, takut pergi ke sekolah, karena orang tersebut tidak mau menjadi korban bullying sehingga memutuskan untuk tidak mengikuti kegiatan di sekolah, trauma, untuk beberapa orang bullying dapat mengakibatkan trauma. Oleh karena itu bullying ini perlu diicegah karena memiliki dampak yang sangat banyak bagi korbannya jika masih sering terjadi di sekolah.

Dampak bullying yang dikemukakan dalam penelitian (Yandri, 2014) ada beebrapa dampak yang cukup nampak seperti halnya dampak yang sangat nampak pada hasil kekerasan fisik, baik berupa luka, memar, lebam, dan rasa sakit yang timbul disekujur bagian tubuh si korban. Kemudian dampak psikis yang ditimbulkan dari bullying ini dapat berupa kondisi sosial yang buruk dan dan efek jangka panjang terhadap si korban bullying. Dampak yang timbul dari perilaku bullying antara lain: siswa menjadi pendiam, merasa ketakutan, merasa cemas, menjadi seseorang yang suka menyendiri, mengalami tingkat kegelisahan yang tinggi dan sering berbohong.

Menurut (Wiyani, 2012) paparan hasil dari penelitian menunjukkan dampak terhadap korban individu yang mengalami bullying akan mengalami kesulitan dalam bergaul karena dalam diri seorang korban memiliki rasa ketakutan dan trauma yang tinggi, dimana mereka merasa takut ketika hendak masuk kelas, yang mengakibatkan absensi siswa menjadi buruk dan tertinggal pelajaran, korban juga akan mengalami kesulitan berkonsentrasi dalam mengikuti pelajaran, dan kesehatan mental maupun fisik korban terpengaruh baik itu dalam jangka panjang maupun pendek. Oleh sebab itu, bullying di sekolah akan menimbulkan gejala yang buruk pada siswa yang menjadi korban bullying.

Menurut (Geldard, 2012) Perilaku bullying disebabkan oleh pelaku karena suasana lingkungan yang memiliki aturan yang kurang baik, sehingga membentuk kepribadian pelaku menjadi agresif maka timbullah bullying dan membuat rasa sakit hati terhadap korban bullying, kemudian korban hanya bisa memendam rasa kecewa terhadap pelaku tersebut. Selanjutnya menurut pendapat Riauskina (Yandri, 2014) dijelaskan bahwa terjadinya bullying disekolah karena adanya tradisi senioritas, adanya rasa ingin balas dendam, ingin mendapatkan kekuasaan dan kepuasan dikalangan adek kelas, karena adanya anggapan bahwa diri korban sendiri tidak berpenampilan sesuai dengan siswa lain (norak).

Peran seorang konselor sekolah sangat penting disekolah, terutama dalam mencegah perilaku bullying yang dilakukan oleh siswa disekolah. Peran guru bimbingan dan konseling dalam mencegah perilaku bullying tersebut yaitu sebagai informator, motivator, fasilitator, 
Peran Guru Bimbingan Dan Konseling Dalam Mencegah Perilaku Bullying Siswa Kelas X IPS 2 Di SMA Hang Tuah 4 Surabaya Tahun Ajaran 2020/2021

mediator, dan evaluator. Maka dari itu, peran guru bimbingan dan konseling dalam mencegah perilaku bullying yang terjadi dalam lingkungan sekolah sangat penting dengan memberikan program layanan bimbingan dan konseling yaitu: bimbingan klasikal, konseling indivudal, konseling kelompok, dan layanan informasi

\section{METODE}

Penelitian ini bertujuan untuk mendeskripsikan peran guru bimbingan dan konseling dalam mencegah perilaku bullying siswa. Desain penelitian ini menggunakan pendekatan kuantitatif dengan metode deskriptif. Pendekatan penelitian ini menggunakan pendekatan kuantitatif karena menggunakan angka, mulai dari pengumpulan data, penafsiran terhadap data, serta penampilan dari hasilnya. Penelitian ini menggunakan pendekatan deskriptif dengan tujuan untuk mendeskripsikan hasil penelitian. Menurut (Sugiyono, 2013), penelitian deskriptif adalah metode yang berfungsi untuk mendeskripsikan terhadap objek yang diteliti melalui data yang telah dikumpulkan sebagaimana adanya.

Penelitian deskriptif adalah metode yang berfungsi untuk mendeskripsikan terhadap objek yang diteliti melalui data yang telah dikumpulkan sebagaimana adanya. Dalam penelitian ini menggunakan deskriptif karena data yang telah diperoleh akan dideskripsikan secara detail bermula dari peran guru bimbingan dan konseling melalui wawancara dan menyebarkan kuisioner untuk menguji validitas perilaku bullying tersebut, agar bisa diambil kesimpulan tentang peran guru bimbingan dan konseling dalam mencegah perilaku bullying siswa.

Instrumen penelitian yang digunakan oleh peneliti yaitu melalui blue print yang dibuat berdasarkan dari variabel penelitian kemudian dikembangkan menjadi butir-butir item pernyataan. Penelitian ini menggunakan skala pengukuran berupa kuisioner mengenai perilaku bullying siswa sesuai dengan instrumen penelitian. Dimana kuisioner yang disebarkan pada siswa sebanyak 26 pertanyaan. Skala pengukuran menggunakan model skala likert dengan 4 pilihan, yaitu Sangat Setuju (SS), Setuju (S), Tidak Setuju (TS), dan Sangat Tidak Setuju (STS). Selanjutnya Teknik pengumpulan data menggunakan angket berupa kuisoner dan melakukan wawancara dengan guru bimbingan dan konseling mengenai jenis bullying yang biasa terjadi disekolah. Sedangkan untuk analisis data, peneliti menggunakan teknik analisis data yaitu menggunakan analisis data uji $\mathrm{F}$ dengan menggunakan program Microsft Excel 2010 dan SPPS For MS- Windows Versi 26.0. 


\section{HASIL PENELITIAN DAN PEMBAHASAN}

\section{Hasil Penelitian}

Penelitian ini menggunakan 29 siswa yang menjadi sampel dalam penelitian yang diambil secara purposive sampling dimana purposive sampling dilakukan dengan pengambilan sampel yang menurut peneliti memiliki kriteria-kriteria yang spesifik, dimana hasil yang diteliti oleh peneliti pada tabel 3.1 sebagai berikut.

\begin{tabular}{|l|l|r|r|r|r|c|}
\hline \multicolumn{7}{|c|}{ ANOVA $^{\text {a }}$} \\
\hline \multicolumn{2}{|l|}{ Model } & $\begin{array}{c}\text { Sum of } \\
\text { Squares }\end{array}$ & Df & $\begin{array}{c}\text { Mean } \\
\text { Square }\end{array}$ & F & Sig. \\
\hline 1 & Regression & 156,283 & 1 & 156,283 & 8,752 &, $002^{\mathrm{b}}$ \\
\cline { 2 - 8 } & Residual & 867,165 & 27 & 32,117 & & \\
\cline { 2 - 8 } & Total & 923,448 & 28 & & & \\
\cline { 2 - 8 } & & & & & & \\
\end{tabular}

Tabel 1 Hasil Uji Statistik F

Pada tabel 1 menunjukkan F hitung sebesar 8,752 dengan tanda positif yang berarti arah hubungan bersifat positif. Hasil uji statistik F menunjukkan nilai sig 0,002 <0,05 menunjukkan bahwa peran guru bimbingan dan konseling secara signifikan dapat mencegah perilaku bullying siswa.

Hasil penelitian yang didapat dari wawancara. Wawancara dilakukan bersama Bapak Otto Prabowo, S.Pd sebagai konselor (guru bimbingan dan konseling) kelas X SMA Hang Tuah 4 Surabaya. Data yang ditanyakan oleh peneliti, dengan wawancara secara tatap muka atau langsung pada konselor, kemudian jawaban diuraikan dalam bentuk kutipan hasil wawancara. Hasil wawancara tersebut menjelaskan jawaban guru bimbingan dan konseling mengenai peran guru bimbingan dan konseling dalam mencegah perilaku bullying siswa.

Pada saat pandemi ini, kegiatan pembelajaran dilakukan secara daring. Perilaku bullying yang dilakukan oleh siswa melalui media internet, guru bimbingan dan konseling belum ada menemukan dan melaporkan kasus bullying melalui media sosial (cyberbullying) yang dilakukan oleh siswa. Sebelum masa pandemi, di sekolah SMA Hang Tuah 4 Surabaya ketika ada temannya yang sedang memiliki masalah, maka temannya melaporkan masalah tersebut pada guru bimbingan dan konseling. Kemudian, sebagai seorang guru bimbingan dan konseling dengan mudah membantu siswa dalam menyelesaikan masalah antara kedua belah pihak tersebut secara langsung. Dengan pertanyaan yang ditanyakan oleh peneliti "Pada saat 
pandemi ini, kegiatan pembelajaran dilakukan secara daring. Apakah selama pembelajaran daring ini terjadi bullying yang dilakukan oleh siswa melalui media internet (cyberbullying)? Jawaban: sampai saat ini belum ada kasus bullying yang terjadi melalui media sosial, saya berharap tidak akan terjadi kasus tersebut"

Bullying yang biasa terjadi disekolah tersebut adalah Masalah yang sering muncul dari bullying yang dialami siswa disekolah ini seperti bullying fisik yaitu mengejek bentuk tubuh dari temannya, warna kulit temannya, Kemudian bullying verbal seperti: mengucapkan kata goblok kepada temannya, dan dikucilkan teman kelasnya karena status sosial dari korban bullying tersebut. Dengan pertanyaan yang ditanyakan oleh peneliti “Apakah siswa di SMA Hang Tuah 4 Surabaya memiliki permasalahan bullying? Bullying yang biasa terjadi disekolah tersebut seperti apa? Jawaban: ada, yang terjadi biasanya dalam bentuk bullying fisik, dan bullying verbal dimana membuat korban merasa sakit hati terhadap si pelaku"

Cara seorang guru bimbingan dan konseling dalam mengatasi perilaku bullying siswa yaitu, pertama kali adalah dengan mengidentifikasi masalah yang dihadapi siswa kemudian sebagai seorang guru bimbingan dan konseling dapat memahami permasalahan yang terjadi pada individu yang bermasalah dan faktor penyebab timbulnya masalah tersebut dimana guru bimbingan dan konseling mendatangkan pelaku bullying tersebut ke dalam ruang bimbingan dan konseling. kemudian melakukan langkah bimbingan penyuluhan, dimana sebagai guru bimbingan dan konseling memberikan bantuan kepada pelaku dan korban bullying agar dapat dibicarakan dan dituntaskan masalah tersebut tidak terulang kembali. Dengan pertanyaan yang ditanyakan oleh peneliti "Bagaimana langkah-langkah guru Bimbingan dan Konseling dalam mencegah perilaku bullying di SMA Hang Tuah 4 Surabaya? Jawaban: sebagai seorang guru bimbingan dan konseling, langkah pertama yang saya lakukan adalah mengidentifikasi masalah kemudian memberikan layanan bimbingan kepada pelaku dan korban bullying tersebut"

\section{Pembahasan}

Menurut (Yandri, 2014) memaparkan bahwa hasil penelitian guru BK dalam pencegahan perilaku bully di sekolah yakni diharapkan dapat mencegah dan membantu menyelesaikan bullying di sekolah. Beberapa peran Konselor dalam menghadapi pencegahan bullying ini dilakukan sebuah kolaborasi antara pihak sekolah dan orangtua dalam menyelesaikan masalah tersebut. Sejalan dari pemaparan diatas peranan guru Bimbingan dan Konseling yang terjadi di SMA Hang Tuah 4 Surabaya yang diperoleh hasil uji F yang dimana diketahui hasil nilai $0,002<0,05$ yang dimana hasil tersebut dapat dijelaskan secara signifikan 
bahwa peranan guru bimbingan dan konseling SMA Hang Tuah 4 Surabaya sudah signifikan dan baik dalam kegiatan ikut serta pencegahan perilaku bullying dengan memberikan program layanan bimbingan dan konseling meliputi: layanan bimbingan klasikal, layanan konseling individual, layanan bimbingan kelompok, dan layanan informasi.

1. Bimbingan Klasikal. Bimbingan klasikal diterapkan oleh guru bimbingan dan konseling di SMA Hang Tuah 4 Surabaya dengan cara memberikan informasi secara langsung seperti guru bimbingan dan konseling memberikan arahan dan motivasi pada pelaku juga kepada korban bullying, dan memberikan pengetahuan tentang perilaku bullying.

2. Konseling Individual. Pemberian layanan konseling individual yang diterapkan oleh guru bimbingan dan konseling di SMA Hang Tuah 4 Surabaya dalam mencegah perilaku bullying disekolah adalah dengan cara memanggil pelaku bullying, kemudian guru bimbingan dan konseling menyanyakan faktor penyebab pelaku tersebut melakukan bullying kepada korban bullying. Lalu guru bimbingan dan konseling memberikan wawasan pada pelaku mengenai dampak negatif bullying yang dilakukan oleh pelaku tersebut. dalam mencegah perilaku bullying tersebut guru bimbingan dan konseling bekerjasama dengan guru kelas.

3. Konseling Kelompok. Penerapan konseling kelompok diterapkan oleh guru bimbingan dan konseling di SMA Hang Tuah 4 Surabaya dalam mencegah perilaku bullying adalah dengan cara membentuk kelompok, kemudian pelaku ataupun korban bullying dapat meceritakan masalah yang sedang dihadapi kemudian dibahas secara bersama dengan anggota kelompok dan konselor sekolah.

Program bimbingan dan konseling yang diterapkan oleh guru bimbingan dan konseling selaku konselor di SMA Hang Tuah 4 Surabaya dalam layanan bimbingan dan konseling sebagai berikut:

1. Layanan Informasi. Layanan yang diterapkan oleh konselor sekolah di SMA Hang Tuah 4 Surabaya merupakan proses pembelajaran dilakukan di kelas dengan memberikan materi mengenai perilaku bullying, dampak perilaku bullying, kemudian guru bimbingan dan konseling juga membuat sebuah poster stop bullying yang di tempelkan dipapan mading sekolah.

2. Bekerjasama dengan pihak lain. Sebagai seorang guru bimbingan dan konseling juga bekerjasama dengan berbagai pihak untuk menyelesaikan perilaku bullying yang dilakukan oleh pelaku tersebut, seperti bekerjasama dengan guru kelas, orangtua, dan 
Peran Guru Bimbingan Dan Konseling Dalam Mencegah Perilaku Bullying Siswa Kelas X IPS 2 Di SMA Hang

kepala sekolah. dengan adanya kerjasama dengan berbagai pihak dapat membantu guru bimbingan dan konseling mengetahui faktor penyebab pelaku tersebut melakukan bullying terhadap korban.

\section{KESIMPULAN}

Berdasarkan hasil penelitian yang telah dilakukan dapat disimpulkan bahwa peran guru bimbingan dan konseling dalam mencegah perilaku bullying di SMA Hang Tuah 4 Surabaya dapat membantu mencegah perilaku bullying dikelas X IPS 2 dari perolehan uji F 0,002<0,05 yang menunjukkan bahwa peran guru bimbingan dan konseling secara siginifikan dapat mencegah perilaku bullying siswa kelas X IPS 2 di SMA Hang Tuah 4 Surabaya. Peran yang dilakukan guru bimbingan dan konseling dalam mencegah perilaku bullying tersebut adalah memberikan program bimbingan dan konseling yang dilaksanakan di sekolah adalah dengan memberikan, layanan bimbingan klasikal, layanan konseling individual, layanan konseling kelompok, dan layanan informasi.

\section{DAFTAR PUSTAKA}

Arikunto, S. (2006). Prosedur Penelitian Suatu Pendekatan Praktik Revisi VI. Jakarta : PT. Asdi Mahasatya.

Geldard, K. (2012). Konseling Remaja: Intervensi Praktis Bagi Remaja Beresiko . Yogyakarta: Pustaka Pelajar.

Priyatna, A. (2010). Let's End Bullying Memahami, Mencegah dan Mengatasi Bullying. Jakarta: PT. Alex Media Komputindo.

Sejiwa. (2008). Bullying: Mengatasi Kekerasan di Sekolah dan Lingkungan Sekitar Anak. Jakarta : Grasindo.

Sugiyono. (2013). Metode Penelitian Pendidikan Pendekatan Kuantitatif dan Kualitatif dan $R \& D$. Bandung: Alfabeta.

Wiyani, A. (2012). Save Our Children From Schooll Bullying . Yogyakarta: Arruz Media.

Yandri, H. (2014). Peran Guru BK/Konselor dalam Pencegahan Tindakan Bullying di Sekolah. Jurnal Pelangi, 97-107. 